Fecha de recepción: julio 2021

Fecha de aprobación: agosto 2021

Fecha publicación: septiembre 2021

\section{The Invisible Factories: Nature's technologies and design of artificial innovation}

Massimo Lumini ${ }^{(1)}$

\begin{abstract}
Wunderkammern showed her Mirabilia, the rarest natural (naturalia) or human-made things (artificialia). Anthropocene makes a Digital Cabinet of TechWonders that makes it difficult to distinguish them. Nanotechnologies manipulate matter at a microscopic level never reached by human tech and generate molecular creatures with extraordinary properties. But despite this, they still can't compete with Nature's sollertiam acting within the Invisible Factories, where cellular communities come to life from inorganic matter. Notwithstanding its extreme designing power, biomimetics has not yet achieved this competence. It will have to listen to lectio naturae for a long time to come in the future.
\end{abstract}

Keywords: Wunderkammern - Mirabilia - Naturalia - Artificialia - Invisible Factories - Biomimetics - Anthropocene - Nanotechnologies - Biological hierarchies - Sustainability

[Abstracts in spanish and portuguese at pages 165-166]

(1) Massimo Lumini (1957) 1982 Architect (Milan), Biomimetics designer and Art's teacher / 1986 -1990 IED-Milan/Cagliari; coordination department of Design for Handicraft Project's Methodology teaching and manager of RND projects on experimental bionic applications for product design (cork, vegetable fibers, wool). 1996 BIONIKONLab's founding to introduce in the public high school the basic-design applied to Bionics, Biomimetics, Design and Technologies for Environmental Sustainability / 2001-2007 lecturer in SSIS-UNICA - Teaching Morphology and Theory of Figuration, transversal approach to Biology, Architecture, Technology, Design / 2013 STENCIL- Trento's MUSE awards as the best project for national scientific dissemination. Since 2002 post-graduate biomimetic design seminars and workshops and training for Engineers and Architects. Publications: 2018, Following Forms, Following Functions. Practices and Disciplines in Dialogue, Cambridge Scholars Publishing / 2018 Biomimetics: Nature's teaching https://issuu.com/massi molumini/docs/issuu https://issuu.com/ferrarif2/docs/scienza_futura_2019 / 2019 Bionica e Design, https://openaccess.blucher.com.br/article-details/10-21895) / 2014 creation of the FABNAT14, one of the most active spaces for innovative. m.lumini57@gmail.com 
Nulla ars imitari sollertiam naturae potest.

Cicero

We cannot command Nature except by obeying her.

Francis Bacon

I am an atheist, I have never understood those who see

the presence of God in Nature: I suspect it only in shells.

Frank Lloyd Wright

\section{The return of Wunderkammern Mirabilia}

From the discovery of the biological algorithm of fractals onwards, SEM, and all-over microscope tech, have shown to man's eyes the charm, the sense of mystery, and the unfathomable depth of Nature's design into his extraordinary ultra invisible manifestations. Through many digital contemporary architectures, forcefully returned to the sensual domains of life sciences, materials technology, structural engineering, and product design, we have rediscovered this deep biophilia enclosed in the rapt gaze that explored the dusty coffers of ancient Wunderkammern Mirabilia or Wonder Rooms of the past. Since the foundation in 1775 of the Royal Museum of Physics and Natural History in Florence-Italy, the institution of the science museum as an orderly collection and cataloging of finds of widespread and educational interest had its roots in those extraordinary collections that they were the Wunderkammern (See Figure 1).

Their presence in Europe is evident from the end of the sixteenth century and throughout the seventeenth century; in turn, they derived from ancient bestiaries and reliquaries of medieval churches ${ }^{1}$.

To entertain and satisfy the curiosity and enjoyment of their guests' gaze, erudite and enlightened princes of the time, used to set up their own precious and rare Mirabilia (from the Latin mirabilis, derivation of mirari 'to admire - marvel'), exhibiting in glass vases, shelves, display cases, and cabinets, the most curious and bizarre finds from the natural world (Naturalia) alongside books and scientific instruments, strange products of alchemical knowledge and mazy handicrafts of extraordinary beauty (Artificialia). A paraphernalia microcosm was offered to senses and fine intellect's pleasure through an original mise en place, with often dreamlike, irrational, unconsciously sensorial features that followed a narration through a secret scenography. Wunderkammern phenomenon represents a really special place; literally, a Theater of the World, which interweaved symbolic references and analogies between the various and confusing shapes, colors, preciousness, rather than submitting to arid dictates of precise scientific taxonomies, which still approximate ${ }^{2}$. 


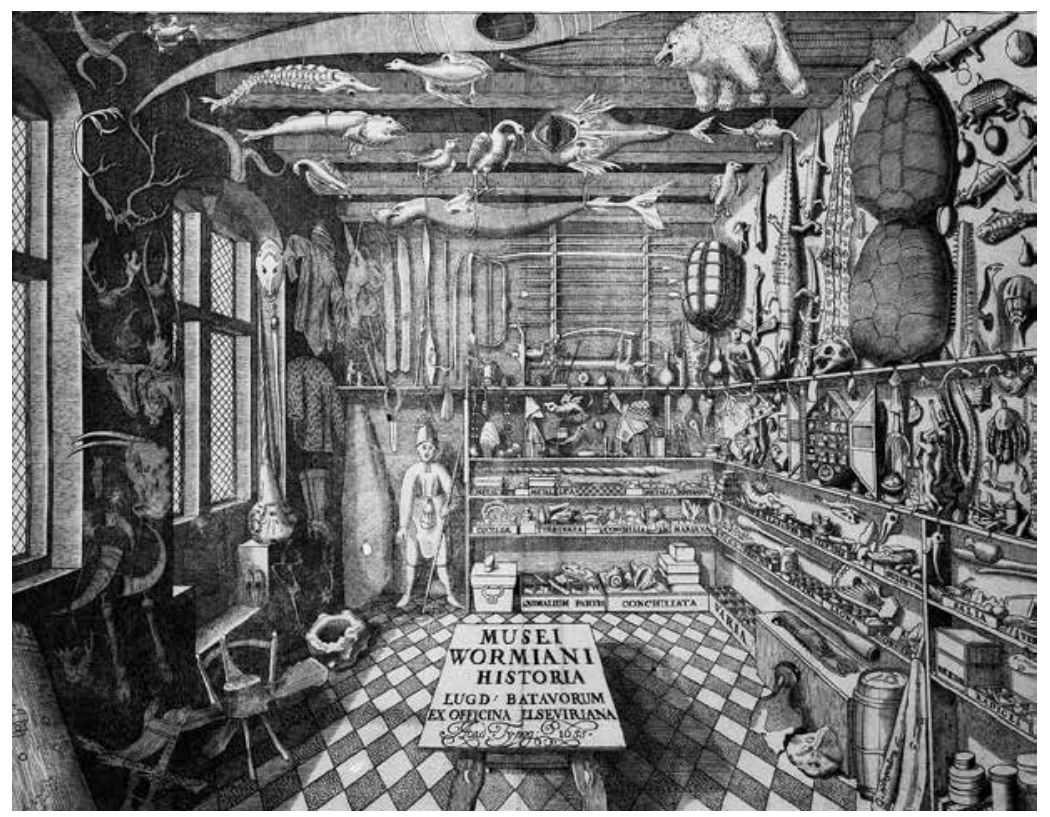

Figure 1. 1665-Frontispiece from the Museum Wormianum depicting Ole Worm's cabinet of curiosities. (Credit https://creativecommons.org/licenses/by/4.0).

These collections will be rationally systematized, as mentioned, only from the end of the eighteenth century. About this fact, it is emphasized that the Latins used two particular terms, first derived from the Greek $\gamma \nu \tilde{\omega} \sigma ı \varsigma$ (gnòsis), to indicate the act of knowing: the verb gnosco-erre, in the specific rational sense of understanding complexity of specific information about a topic or an art, hence the Italian term conoscenza, and the verb săp̌roére which can be translated as "to have taste", "to have a smell", "to be wise, sensible or prudent", hence Italian modern sapere (the knowledge).

This etymological path demonstrates how the ancients, in the sacred respect of the dialectic between Apollo's and Dionysus dance, were deeply aware of the importance of organically and vitally grasping and connecting the aspects linked to the logical and rational cerebral categories with the taste and the irrational thrill of aesthetic and sensorial contemplation. Intellectual pleasure did not deny that it compromised and entertained itself with aesthetic pleasure; on the contrary, these categories were intimately connected and complemented each other.

The cosmic hedonism of a certain neo-pagan Renaissance's humanism celebrates overcoming the privations and sensory pains of medieval thought by rehabilitating the dignity of the sensitive knowledge and its importance in the born of the scientific method ${ }^{3}$. 
We find, in the desire of these proto-scientists to possess the entire possible Universe in a surprising private glance, the thirst for knowledge and rational control of natural phenomena. This ratio was combined with the intimate human need for wonder and amazement, never repressed towards the sparkling, mysterious, and surprising spectacle of the sensitive kaleidoscope of natural phenomena forms. These emotions are typical of the state of enchantment, and we can understand them as the deepest motives that animate human knowledge and scientific discovery of all times (in the dynamism cited between gnosco and sapio) and of scientific discovery of all times. Incredibly saturated with things never seen before, in Wunderkammern's visual experience, what aroused more than anything else the pleasure of the aesthetic unveiling of the infinite creativity of the natural cosmos was the presence of disturbing animals barely imaginable. An exuberance of stuffed animal bodies from the most remote places dangled like gruesome trophies from ceilings and walls. In the contemporary return of the realms of invisible wonders, are valid the reflections of the famous scientist Richard Feynman, quoted by Caspar Henderson and conceived in the observation of extraordinary animal or plant creatures, of which we continue to discover details of unparalleled biological technology:

Our imagination has to try hard not to imagine things that don't exist, (...) but simply to understand things that actually exist ${ }^{4}$.

Start from Aristotle's interests in natural phenomena, to understand the things that exist as tangible, the ancient speculation and the philosophy of science have tried to recreate the order and a coherent structure of Nature's creation, perceptible to human reasoning. One of the speculative products that have persisted in the history of science and in the eyes and senses of the man's intellect is undoubtedly the image of Scala Naturae; literally Ladder of Being and often translated as the Great Chain of Life ${ }^{5}$.

From the lowest step of inanimate matter, through passages on a dimensional scale and increasing organic complexity, one could pass from the inorganic domain of stones (lapis) to ascend toward the divine metaphysical empyrean (Deus), gradually climbing the successive morphological hierarchies of the Universe (flama, planta, brutu, homo, celum, angel) (See Figure 2).

In actual scientific and technological research's protocols, the main structural idea of the passage of dimensional scales, inherent in the Great Chain of Life's archetype, is experienced by Scientists using extremely powerful and accurate microscopes.

In this perceptive sphere, the metaphor of the Invisible Factories (after this referred as I.F.) is born. We can refer to them as an elusive and imaginary archetype that involves both natural and humankind's design. Indeed, all industrial processes and material world products, made by the Great Acceleration economic trends, are superimposed and mixed with the planet's ecosystems by the technoscientific and digital progress of the so-called Anthropocene. They create a new kind of hybridization between artificial and natural design never experienced by the living terrestrial ecosystem network ${ }^{6}$.

Nowadays, design thinking is inspired and nurtured by the deep sensory experience of invisible matter in ways never known in our technological and scientific evolution. Human vision is constantly immersed in some Planet Augmented Tech-Wonders Cabinets. 


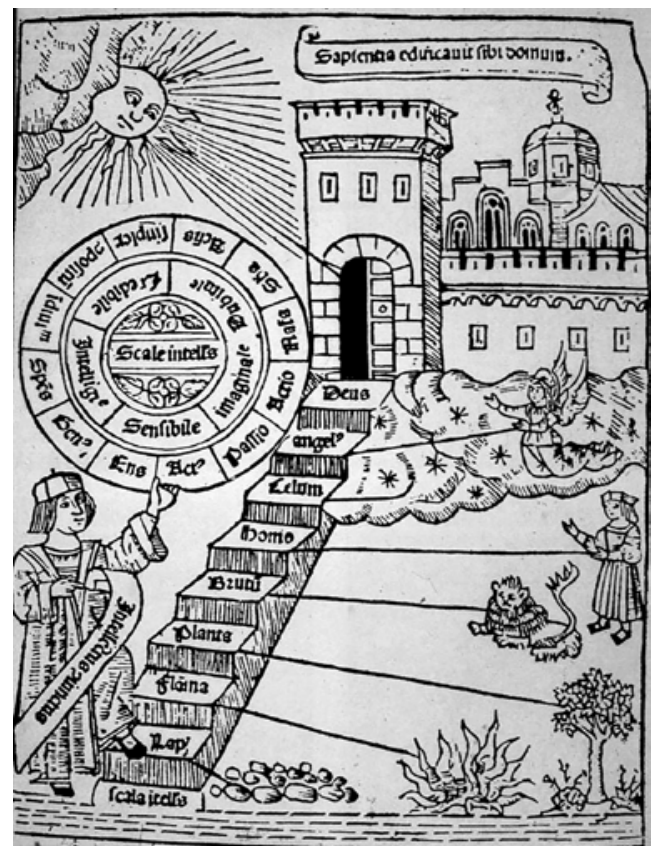

2

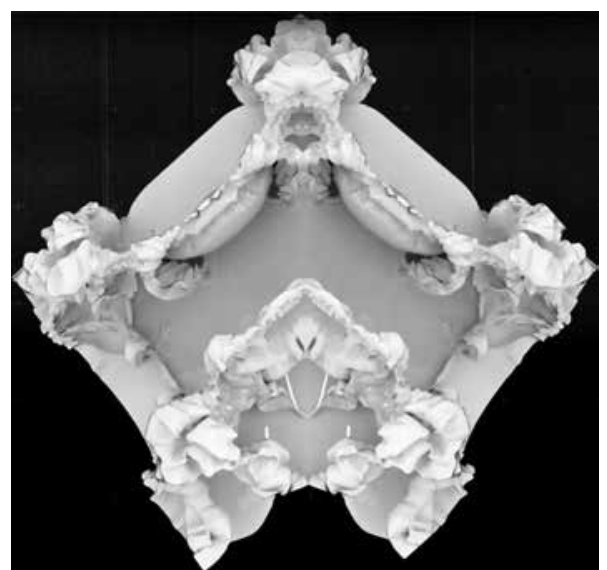

3

Figure 2. Xilograpy from book of Raimondo Lullo, De ascensu et descensu intellectus, Valencia, 1512 (Credit http:// www.uni-mainz.de/presse/25888.php). Figure 3. Domínik Cisař, Digital Rococò (Credit https://www.behance.net/ dominik81d2).

The current imaging protocol has imposed itself in science, high-tech, and CAD-design with specific and sophisticated digital mirage and genetic enchantment characteristics, with still unknown psychological and cultural effects. It is increasingly difficult to distinguish and separate the boundaries between the ancient mirabilia categories of naturalia and artificialia. In imaginary Nature's mimicry territories, many technological creatures are generated by bio-algorithms that try to emulate the extraordinary genetic vitality of the organic forms and functions. This sort of digital rococo takes on an aesthetic and formal expression where a hybrid ecosystem pervades all the aesthetic languages of architecture and product design as can be found in Marijan Colletti's or Domínik Cisař's theories and design work (See Figure 3$)^{7}$. 
If transferred into the technoscientific domain, this powerful generative capacity is to the point of assembling molecular creatures with extraordinary life-like attitudes and creating new materials and nanomechanical tools endowed with sophisticated chemical-physical properties of self-assembly or shape memory at an unprecedented microscopic level of detail and functionality. However, even though it is now possible to manipulate atomic and subatomic entities on a microscopic level never reached by human skill, through this nanotechnological esoteric processes of physical chemistry, the mystery and zeal of life are still unknown in much of their true nature.

But they still never shine with a life of their own, and the umbilical cord that binds them to the limits of man's I.F is far from being severed. They are only the first cry of a newborn genealogy of actually oblivious synthetics creatures, designed by human intelligence for unknown effects of a futurible evolutionary hybrid scenario. All these facts happen while many design suggestions are inspired by never seen ultra-thin layers of chemical awareness, self-representation, and complex cellular bio-cooperation, that continually emerge from the I.F. of Nature realm to inspire future human challenges. The following comparison step between human and natural product design of I.F. will be completely played out at this nanometric dimensional scale on the challenge of vital awareness. To the limits of our astonished gazes, the consideration about hierarchical design-chain of life, for its floating capacity to emerge from the bottom of the atomic and molecular forge to visible's level of life's patterns of a satisfying experience, is revolutionized through extraordinary increased vision. These technologies allow extraordinary visual enlargements that amaze, disconcert and baffle human thought that gets lost across the available plethora of material ultrastructures.

These experiences demonstrate a Nature's Chem\&Physics design intelligence which is displayed and vouched at every resolution scale. This path starts from living matter's molecular organic form-functionality to reach the ecological interconnected planetary dance. Hypercomplex networks of beings are decoded in the extraordinary archive of contemporary digital Neo-Wunderkammern big data. Biomimetics, which is defined by the biologist Janine Benjus as the conscious imitation of the genius of life as a survival strategy for mankind and a path towards a sustainable future, is the one most committed research's protocol among all the current bio-sciences to the goal of building ground for dialogue and analog transition between natural and human design ${ }^{8}$. It is gaining valuable information and a great creative impulse precisely from the use of these highly detailed images of ultramicroscopic morphologies capable of showing impressive architectures in the design and functional details of nanometers $\left(10^{-9}\right)$ range organic structures. The visual sensory descent by modern digital eyes through the steps of the ancient Scala Naturae towards the indefinite boundaries between organic and inorganic, living and amorphous, is redefining the semantic meaning of terms such as: simple and complex, elementary and evolved, organic and inorganic, natural and artificial. The work of researchers and designers from all over the world focuses on the collective effort to rebuild a possible evolutionary deeper meaning of this visual scientific alphabet, stalking interpretative life's fil rouge through the labyrinths of marvelous biological ultrastructures network, becoming disoriented in describing the elusive transformation of matter's vital dynamism. The ancient Mirabilia feeling appears today more current than usual in the retinas of scientists. Although we 
have drastically expelled from contemporary scientific theories, any plausible acceptance of vital impulse at works in the constructive intentions of matter. It is entirely not demonstrable to human existence itself; even today, the life's mystery interpretation continues to elude us in its most profound and most significant origin. But it is difficult for the human sight feeling to remain unduly objective in the presence of so much and so advanced structural intelligence and design strategy. They manifest themselves visible and functional through all the links and correspondences between the biological hierarchies that build and manage the gestalt of bodies and the existence of beings simply extraordinary. And this new altered taxonomy starts own from those defined as primitives, coming from the darkest archaic ages and once classified at the lowest rungs of the living. In this hallucinatory journey through life's exuberance (from the Latin uber= fertile), the eyes and the mind gathered in the communion of biophilic signature. They come into contact with the infinite diligence (sollertiam) of these laborious I.F. that have been producing biofacts for billions of years in their alien and apparent elusive simplicity.

These are organic architectures that are barely imaginable to human thinking, where molecular forges pulse with intelligence and technological strategy; cells and organelles are present, brisk, wired, connected to the ambient, and active in all imaginable scalable dimensional passages. Exciting biochemical details of these primordial beings that make up, for example, the phylum Porifera (literally carriers of holes), who were the first animals to populate the planet, are continually discovered. Of the approximately 15,000, only 9,000 have been classified and studied in detail. They are mistakenly classified as basic, simple, and flawed, destined for subsequent evolutionary improvements by Nature on their way towards increasingly complex and human-like structures. We yet consider us the whole paradigm of the complexity of creation. A typical example of this process assumes the unique structural and technological biodesign concept that the sponges like Euplectella aspergillum show, which are considered among the oldest and most basic living beings of the entire structural framework terrestrial ecosystem. The sponge's fossil record dates back more than half a billion years; the Neoproterozoic marine (Demospongiae and Hexactinellida) represents one of the oldest cellular metazoan multigroup capable of synthesizing mineralized siliceous structural materials such as spiculae. This extraordinary scaffold typology was engineered by Nature in an authentic and divergence way, really far from the vertebral system design thinking.

Because sponges had chosen the aquatic life scenario, their problem-solving's efforts were busy to imagine how to optimize resources and mechanical, hydraulic stresses to satisfy the vital challenges of your own body. The water's and sea's cellular humid intelligence build an original skeleton concept by creating a structural module invention (spicula) made by collaboration between bio-entities (amoebocytes / sclerocytes / collagene) that they were able to imagine a structural system able to build an ingenious knotty engineered scaffold. The typologies of spiculae occur among the various species in a highly differentiated way, but they are all made from the vital tissues of the hydrated sponge amorphous silica and are broadly classified into two categories based on relative size and role in the skeleton: megascler and microscler (See Figure 4). 


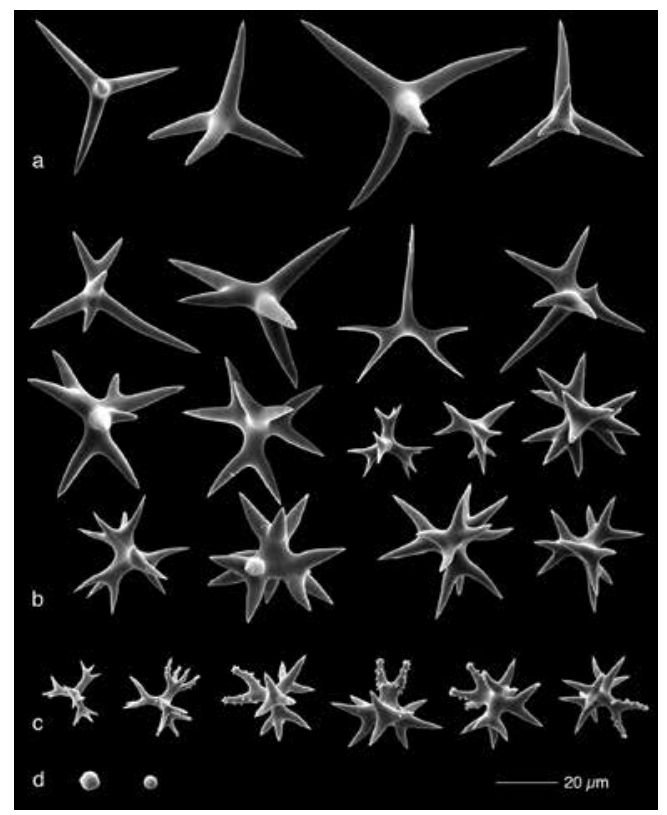

Figure 4. Corticium quadripartitum, spicules (SEM): a: calthrops; b: lophocalthrops; c: candelabras, d: spheres (Credit https://www. researchgate.net/ profile/MariaDiaz-23).

This excellent design concept provides the animals with architectural support equipped with a highly flexible mechanical resistance, helping them extract food through filter systems and protect themselves from their environment. The sponge's body structural organization was a unique reciprocal framework solution, engineered by Nature in an authentic and divergence way, so really far from the next evolutive vertebral system design thinking ${ }^{9}$. Spicula is an alienating biodesign result: a mirabilis microscopic three-dimensional joints with an engineering design that seems to come out of a catalog of structural steel components of a human factory, like some that are conceived by the creativity of Richard Buckminster Fuller (1895-1983) or Konrad Wachsmann (1901-1980). The sponges were among the first Nature's I.F. in which in their construction layout it is possible to identify a real bio-assembly line, where specialized cells can extract from the seawater the raw materials useful for the construction's modules biomineralization, and other cells, literally like serial workers, that collect and move the spiculae that will join in a complex structure, by gluing them with collage inside the body of the animal, as observed in Ephydatia fluviatilis, a freshwater sponge ${ }^{10}$.

Bio-inspired engineering of porifera structures and the morphology of diatoms and radiolarians, have become a hot topic in science and design. The goal is first to understand how the mechanical concept of this biological structure can improve the performance of the entire project and then apply the underlying physical response principles to create new human-made forms: 
The microscler exhibit a fascinating diversity of the most intricate species-specific threedimensional (3D) morphologies displaying high spatial regularity and symmetry. Surprisingly, fabrication of such hierarchical complex glass structures still seems to be far beyond the reach of current human technology. Numerous studies of glass sponges skeletons suggest that the unique fracture toughness results from the spicules cylindrical layered architecture. However, Monn et al. discovered that while interfacial fracture does improve the toughness of the cylindrically layered beam, its impact is relatively small compared to the arrest and re-nucleation mechanism that occurs in the planar layered beam. This finding is questioning this theory and shows that the understanding of the relationship between layered architectures and toughness enhancement is not yet complete ${ }^{11}$.

This intricate network of biochemical responses with teleological-functional purposes can define, in the living organisms, a particular and customized overall technological and morphological design. Many questions are still unsolved by scientific research, which still struggles to understand the complex dynamics that underlie the ability of cells to work in the best possible way to allow the organism, in its integrity and complexity, the correct efficiency in responding to existential challenges and activities related. For example, to optimize the body's locomotion or to devise the most sophisticated solutions applied for the specific processing of the shape arrangement and expressed in the characteristic conditions of a terrestrial, liquid, or aeriform environment.

It is also significant that, through creative and daring analogical procedures, some architectural and geometric-structural concepts, inspired by the archetypes of natural geometry, have been transferred with enormous success into transversal scientific research fields. We note many compelling cases of this continuous feedback between natural and artificial areas. It is also significant that, through creative and daring analogical procedures, some architectural and geometric-structural concepts, inspired by the archetypes of natural geometry, have been transferred with enormous success to transversal scientific research fields. We note many compelling cases of this continuous feedback between natural and human-made areas. For example, we can refer to the well-documented case of applying the structural concept of Tensegrity to cell biology. In the early 1950s, American architect-sculptor duo Richard Buckminster Fuller/Kenneth Snelson created inedited Tensegrity architectures to describe structures whose stability and integrity lie on a state of pervasive tension forces rather than continuous compression as in the notion most common gravitational (e.g., brick by brick). Tensegrity was used as a suitable functional model to describe the biomechanical and cybernetic behavior of the cell cytoskeleton, operated through the American cell biologist and bioengineer Donald Ingber (2003-2006). The contamination of fields of knowledge so distant from each other, such as biology and architecture, has generated mechanobiology. The analog transfer that went to create is a new area of research, focusing on how cells control their mechanical properties and how physical forces regulate cellular biochemical responses. This process is known as mechanotransduction (See Figure 5) ${ }^{12}$. 


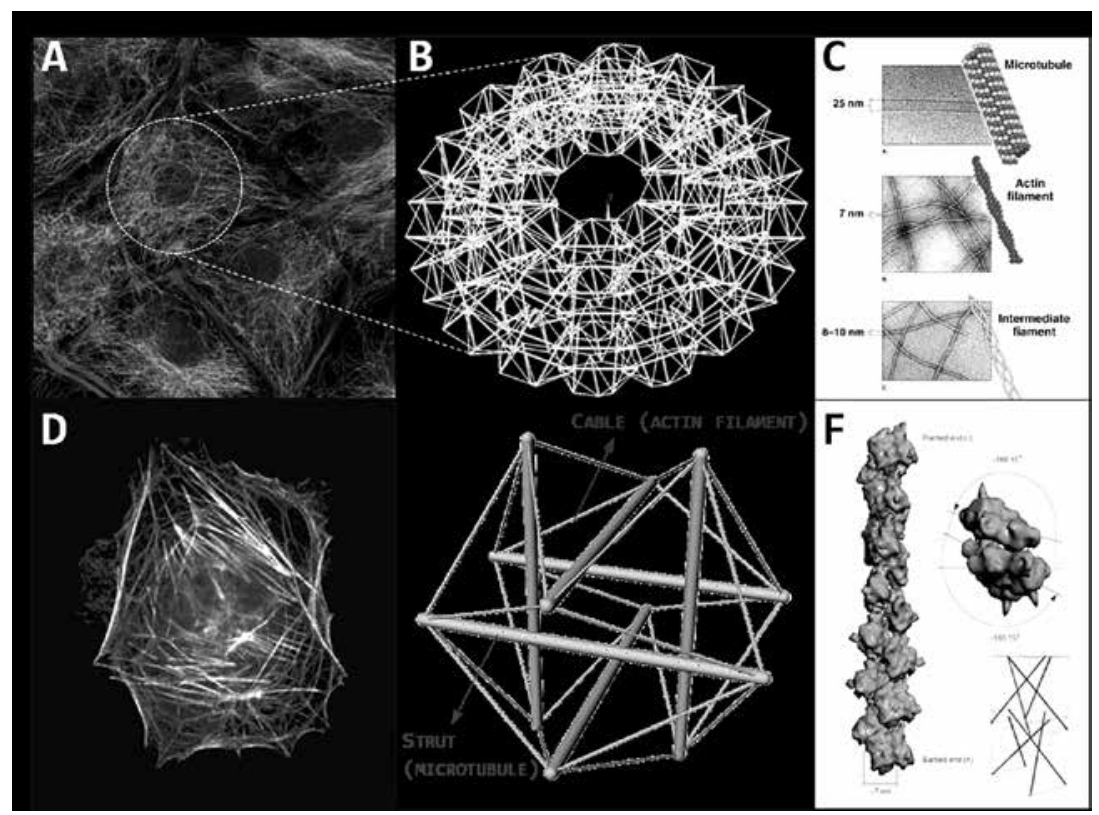

Figure 5. Tensegrity model on cellular cytoskeleton analisys - Donald Ingber (Credit https://www. sciencedirect.com/science/article/abs/pii/S0022509618305660).

The integrated mental habit of Biomimetics' researchers represents, in the culture of design, the remake of a contemporary esprit de finesse that interacts intensely with the corresponding esprit de geometrie of digital parametricism. Above all, we find their privileged field of existence in biology and its specific morphological research. The visual observation of the shape of living beings is still today a central and characterizing aspect of living beings studies and scientific research and the possibilities of developing specific scientific theories. Morphology starts from the acute definitions and experimental considerations that Johann Wolgang von Goethe illustrated in his original naturalistic works, The Metamorphosis of Plants, published in 1790. He defined Morphology as the visual and conceptual interpretation of the perceived thing, rather than the abstract affirmation of the unperceived thing, as in the chemical-physical disciplines (Giacomoni, 1993).

Today research uses ultimate and sophisticated optical amplification devices based on ESRF-Extremely Brilliant Source (ESRF-Ebs). These are technologies that lead human observation to increasingly overcome the limits of the infinitely visible, which were unimaginable only until a few decades ago. The naturalist's analytical and morphological approach to biological beings still occurs mainly through the exploration and visual identification of their geometric shapes. The success of a scientific theory still depends today, as hap- 
pened in the past research work of Leonardo da Vinci, Charles Darwin, Ernst Haeckel or D'Arcy W. Thompson, on the ability to analyze and describe biological samples to deduce appropriate theories (in the etymological sense of the Greek vision) and all these words well accompanied by graphics, artistic drawings, infographics, photographs, and digital maquettes.

Designers, architects, and engineers use sophisticated high-definition images captured by the lenses of tools such as SEM (Scanning Electron Microscope) as typological abacuses for new bio-inspired designs. In the complex act of understanding the human mind of what appears to the eye, forms are captured in its environmental manifestation by the predefined attitude of human perception to organize elementary sensations into figures that emerge on an undifferentiated background. In some cases, the living forms appear imperceptible, often unconsciously obeying the neurophysiological and psychological rules set out in Gestalt-Form Theory (Wertheimer, Köhler and Koffka, 1921).

In I.F.'s contest, the term structure, (from the Latin struĕre - 'to build') is understood through a double meaning. The first considers the $s$. under the purely technical aspect related to fields of biomimetic application in architecture, structural and materials engineering, or industrial design. As such, therefore, the s. it is configured as a Gestalt, that particular arrangement or better organization that individual parts or build modules assume within an integrated whole, capable of responding to precise mechanical stresses internal and external to the organism itself, such as guaranteeing optimal resistance to the forces of compression, traction, torsion, etc. The second definition of $s$. he always considers the Gestalt of the final organism but in terms of gestaltung (doing), that is, of action, as if it were a precise and conscious constructive process in progress. Gestaltung can be understood as a guided bio-manufacturing activity, a dynamic and hierarchical process that trespass from the inorganic through successive levels of planning towards the organic. Gestaltung considers the overall design and structural idea shown by the live's body due to the sum of dynamism and the interaction of building modules on an increasing dimensional scale. Through complex structural hierarchies and sophisticated molecular bio-feedback networks, from the bottom of I.F, where atomic and molecular forge the matter scaffolds, life emerges along the Scala Naturae to the human domain of the visible to the naked eye, identifying themselves as a body in action. Through complex structural hierarchies and sophisticated molecular bio-feedback networks, from the bottom of I.F, where atomic and molecular forge the matter scaffolds, life emerges along the Scala Naturae to the human domain of the visible to the naked eye, identifying themselves as a body in action. We find a precise paradigm of this process in the technological research of the German engineer Claus Matteck. Through observation of morphological-structural behavior of trees and their cellular network morphology, concerning endogenous and exogenous environmental stresses, he has developed a structural theory and a problem-solving defined Computer-Aided Optimization design procedure (CAO-method). CAO system is functional to verify lightweight technical solutions in industrial design, in analogy to the processes related to the principle of adaptive growth of biological structures that trees use to minimize stress concentrations on the surface and which is schematized by Matteck in intuitive and straightforward sketches. 


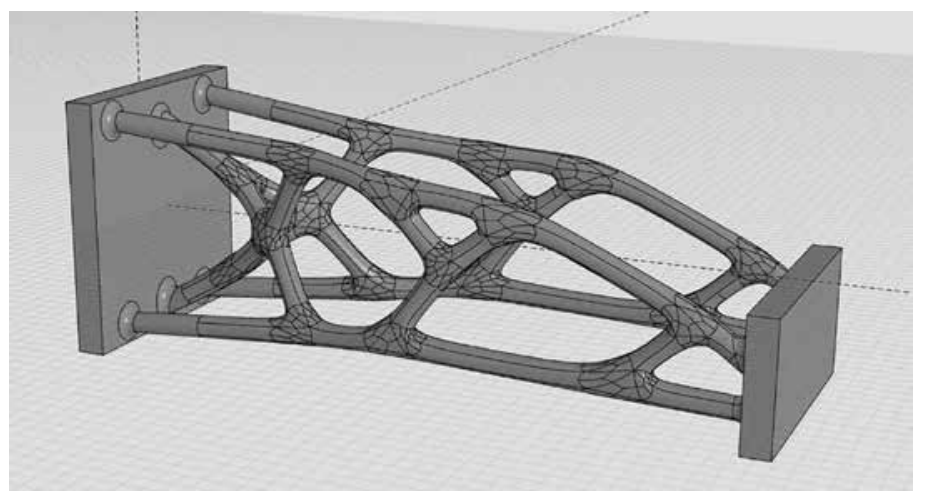

Figure 6. CAO

- Example of a generating biomimetic design patterns (Credit https://www.elise. de/applications/ bionics/ )

The results of Matteck's researches illustrate very clearly the profound difference that still exists between the engineering methods of building materials and the management of energy flows, adopted in the industrial chains of human production, versus the structural and the technological processes that are present and active in the industrial bio-production of natural I.F.

The axiom of uniform stress is identified as a basic design rule for biological load carriers. Based on this condition and by use of the Finite Element Method (FEM) three computer programs have been developed at Forschungszentrum Karlsruhe to transfer these biological optimization mechanisms to mechanical engineering as well as to simulate biological growth. The Computer Aided Optimization design procedure (CAO-method) simulate the principle of adaptive growth which biological structures, like trees, use to minimise stress concentrations on the surface. The Soft Kill Option (SKO-method) copies the biological optimization mechanism of adaptive bone mineralization. And finally the Computer Aided Internal Optimization (CAIO-method) optimizes the performance of composite materials by aligning the fibre distribution with the force flow in order to avoid shear stresses in between the fibres, again mimicking the structure of trees ${ }^{13}$.

The modular cellular units, on which are built all living beings' material ultrastructure, are constantly subjected to complex flow field forces (gravitational, mechanical, biochemical, electromagnetic, and cymatics) that create a sort of fairing and energetics scaffold capable of orienting its morphological processes. Their ability to interact with this complex morphology field, combined with personal capacity for self-assembly, form memories, collaborative chemical processes, developed through millions of years of RND, can determine the most appropriate strategies of the overall bio-design project as we are possible 
to see in the various steps of scale that accompany the construction of human tendon. It is organized hierarchically, with type 1 collagen oriented parallel to the mechanical axis. The assembly begins with three intracellular peptide alpha chains (two alphal chains and one alpha2 chain) that organize into a procollagen triple helix structure.

\section{The rise and fall of Human Visible Dirty Factories}

The exquisite design and technological-structural nature of Homo Faber's creative intelligence have progressively manifested and imposed themselves over time on the planet at such an imposing level of impact as to define our age as Antrophocene- The Man's Era. The physiology of the human body, which allows the brain to develop a type of thoughtform and action-form unique in the natural context, has permitted the technological action in a constant desire to freed from own biological state of featherless biped ${ }^{14}$.

In fact, unlike all the vast family of terrestrial living beings that appeared in the 3.8 billion years of planetary history, precisely to man, the alleged apex of creation has not been given to him a default specific ecosystem. A unique ecosystem seems to have been attributed to the primordial human super couple, but, due to a severe error of assessment, this mythical ecological paradise, which was built specifically for them, turned out irretrievably lost. Thrown naked and raw from the mists of time on a hostile, lethal planet, mercilessly regulated by the more brutal Darwinist laws, humanity seems to be in a perennial search for a lost Promised Land. Across the time, thanks to their design intelligence, human societies have always imagined and crafted their own different and evolved artificial ecosystems, unique and not belonging to the bio-network of the planet.

Artificialia has slowly but inexorably assumed, as a specific human power, characteristics of extreme techno-scientific arrogance without limits and the complete detriment of the equilibrium of the terrestrial ecosystem. We are witnessing a very heavy high-tech overlap on Naturalia, through planetary plundering and the frenetic transformation of all possible raw materials and entire natural environments. The progressive process of detachment, laceration, or instead weaning from Mother Nature took place at the cost of enormous efforts and sacrifices. After an ancestral period of submission to the planet and its cosmic forces, humanity is taking over the governance of the body of Gaia through its economic and technological super-taxation.

Over the very long human dramatically spent on earth, under the motto of blood, sweat, and tears, at a certain point, instantly, if considered in earth's historical-temporal eras perspective, the human's technological nature, between the mid-18th century and today, has produced a feverish escalation, a Great Acceleration growth in time by the advent of the so-called Industrial Revolutions.

Over the very long human dramatically spent on Earth, under the motto of blood, sweat, and tears, at a certain point, instantly, if considered in earth's historical-temporal eras perspective, the human's technological nature, between the mid-18th century and today, has produced a feverish escalation, a Great Acceleration growth in time by the advent of the so-called Industrial Revolutions. 
From the Coal Age, through the Steel Age, the Oil age, and the Bit Age, thousands upon thousands of Human Visible Dirty Factories (afterward H.V.D.F.) have been built and run on the planet.

Their activity has determined, in a handful of centuries, a planetary degradation to the limit of irreversibility, producing extreme and very dangerous environmental imbalances, with a global impact action mainly due to the non-circularity of the industrial metabolic activity with its huge energy consumption and related masses of waste products. The same goes for the overflowing supply of material products created for the daily use of crowded human communities, with particular evidence in these times, such as the problems arising from the dysfunction of the disposable plastic-polymer packaging system of most consumables goods.

The old H.V.D.F. rise and falls and are transformed into a new form of Industry4.0, more ineffable and dematerialized, with futuristic evolutions of the production layout. As never before, they tend to converge towards the I.F. of nature. Technology, aimed at competing with it for the dominance of the ultra-invisible. The competition between the two technological systems currently marks critical points in favor of the human one, which through significant developments in its ability to manipulate the nanometric domain, has reached the possibility of producing materials and machinery of the dimensional order of robots and molecular motors:

"Top-down" (physical approach), consists in reaching the nanometric dimensions, starting from a material of greater dimensions, where the massive material, "bulk", is divided into smaller particles, using mechanical, chemical or other forms. "Bottom-up" (chemical approach), also called "molecular nanotechnology", refers to the synthesis of the nanoparticle material through the condensation of atoms, molecules or radicals thus allowing the precursor to grow with the desired dimensions and characteristics ${ }^{15}$.

But the human manufacturing capacity, due to the overwhelming quantity of production, is still engaged in factories and industrial structures of old conception both from the energy point of view and for the logic of their production cycles that are not yet integrated into a circular economy dimension, in analogy with that of natural production systems. Precisely, the systemic analysis of the theme of synthetic polymers by petroleum derivation contains one of the most acute problems relating to the unnaturally of the processes and products of human technology. The discovery and exploitation of crude oil still have a technological matrix similar to the medieval alchemical principles of material molecular destructuring through the exothermic processes of solve et coagula.

The technological-industrial model of the Athanor, the mystical furnace of first chemistry, is found hand in hand in the fractionation tower, which sometimes even takes the name of the distillation column, replicating exactly the alchemical modality of modifying the molecular-energetic state of the raw material (crude) different trough cycles of thermal shocks. 


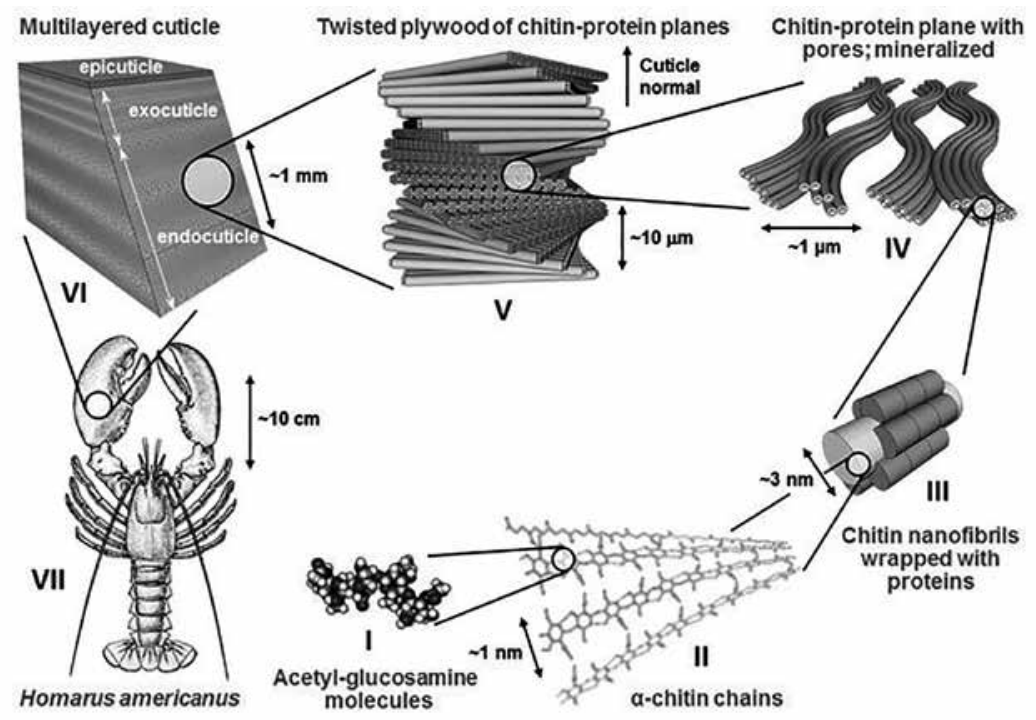

Figure 7. Structural hierarchy of the cuticle of Homarus americanus (Credit https://www.researchgate. net/profile/Svetoslav-Nikolov-4).

Nature also produces polymers. It has been doing it since the dawn of time but with abyssal (in the literary sense of the term) different technological and industrial logics as in the case of chitin. Humanly discovered by the french chemist and pharmacist Henri Braconnot in 1811 , chitin is one of the main structural bio-components adopted by life. For example, it is the main component of the exoskeleton of insects and other arthropods, of the cell wall of fungi, of the perisarch of hydroids. It is also present in the epidermal cuticle or other surface structures of many other invertebrates. After cellulose, chitin is the most abundant biopolymer present in nature. From the chemical point of view it is a polysaccharide, consisting of several units of $\mathrm{N}$-acetylglucosamine ( $\mathrm{N}$-acetyl-D-glucose-2-amine) linked together with a $\beta-1,4$ type bond, the same as the glucose units that form cellulose:

Biological structural materials differ fundamentally from most man-made structural materials, in being inherently structurally heterogeneous. This heterogeneity arises from a multitude of different constituents already at the molecular level, including mainly various organic molecules, such as proteins or sugars, but also inorganic matter, mostly in the form of calcium-based minerals (See Figure 7$)^{16}$. 
When we try to compare, on the same level, the invisible natural factories with the visibly dirty human factories, the gap that still exists between the two production systems is dramatically highlighted. A gap that sees human activity still in a position of enormous inferiority both from the point of view of optimizing the performance and efficiency of the materials produced, mechanics and structural design and from the point of view of the use of energy sources used (oil versus solar energy for example) both in the economic circulation of the waste line and for human production represents a very serious problem. These are yet the H.V.D.F. characteristics, seen in the whole of the present planetary system:

- poorly connected in an artificial industrial network eco-system

- subject to linear/exponential production/waste cycles

- little inclined and inert to change and systemic adaptation

- produce toxins in the long term

- depend on non-renewable sources such as oil

- maximize the objectives in a purely economic-financial function

- extractive and demolitive at the origin of the recovery of raw materials

- there are no limits to development except in a strictly speculative / financial key as an end in itself

- they are embedded in a Darwinistic and egotic competitive economic global scenario

On the contrary, the Natural I.F. are active on the planet for 3.8 billion years in the light of their infinitely tireless molecular diligence. They experiment and apply the successes of the industrial, technological, and bioeconomic following characteristics models

- global interconnection according to network logic (see intreenet)

- activity made through circular logics of energy use and production systems with zero

final waste

- mutant, metamorphic, continuously and rapidly adaptations skills and bio-feedback about the surrounding environmental conditions

- no long-term discharge toxins on the environment

- dependence on renewable sources (solar energy)

- efficient optimization as a function of systemic feedback

- generativity in the supply of raw materials

- themselves limitation to each other through complex logics of general dynamic equilibrium of the production and consumption system of the product and raw materials

- inclusion in a hierarchical and complex system of cooperation and mutual construction

The deepening of each of these aspects that characterize Nature's technological process, is outside the target of this discussion, but it is possible to consider a paradigmatic example. Let's try, by way of applying the proposed scheme, to find a human material that shows some performance characteristics more or less similar to those that chitin offers to live organisms that have been decided in past eras and still choose today to produce and use this molecule for their existential purposes. In this sense, we can refer to Kevlar@, which is used, for example, in the manufacture of military helmets or in bulletproof vests (that a 
closer look from the point of view of design is a human body's protective exoskeletons). If we analyze, for example, the chitin's use as a structural material in the shell of an arthropod, has a bottom-up constructive logic, based on raw materials extraction from the same neighboring environment and biochemical production at low energy impact in ambient temperatures and often in an aquatic, sweet or salty environment. All processes happen by shaping sophisticated nanometric layers of bio-chemical ultrastructure and their gradual physical-mechanical shape emergence at higher dimensional body levels. The interest in biomimicry focuses, above all, on the design of this nanometric module which is articulated in its body structures according to highly specialized 3D textures.

It is exciting to observe, through detailed SEM images, the effort made by the cellular organelles that are invested with the role of makers and carpenters to try to optimize and equalize the individual biomechanical and performance functions necessary for the functional existence of the animal with marvelous technological solutions. Chitin, which in life responds brilliantly to a series of remarkable biomechanical and operating performances, when the organism dies rapidly decays into chitosan thanks to the solvent action of water and in a few days of demolition of the metabolism by the environment, returns in the environment returning the compositional elements ready for subsequent biochemical use: carbon, hydrogen, oxygen, and nitrogen. Chitin, chitosan, and cellulose are three inventions of Nature that are chemically very similar to each other but possess several interesting biochemical and physical-mechanical properties that have allowed these materials to predominate in the material construction of life and to persist in their evolutionary success along the earth ages. $\operatorname{Kevlar} \odot$, darwinistically speaking, was a material that emerged according to serendipity processes. Coincidentally around 1965, these molecules appear by chance in the research work of Stephanie Kwolek, a researcher at DuPont. In anticipation of a possible decrease in oil, she was looking for a solid and elastic fiber to replace the rubber in tires to make them lighter and make the engine consume less petrol for the movement of the car. Two monomers joined to create a polymer, a fibrous compound with characteristics of particular merchandise versatility that convinced the researcher to carry out the first tests and to conduct in-depth research up to the creation of the first aramidic fiber. The production of Kevlar@ $\odot$, as for almost any synthetic plastic fiber, requires high temperatures and subsequent cooling processes, in already considered alchemical vision of Athanor's solve et coagula (See Figures 8 and 9).

The polymer's technological cycle consumes a large amount of thermal energy, producing highly toxic fumes. At the end of its life cycle, its disposal is complicated because it is not biodegradable except over an extremely long time. Man in his H.V.D.F. has generated technological processes and produced materials by grossly imitating natural problem-solving without deeply understanding his systemic and ecological bio-industrial logic.

Today, thanks to the remarkable development of techno-sciences, to a renewed spirit of a new alliance with Nature, and the speculative pressures of the production system, that are beginning to see large profits in the sector of the circular economy, green and blue economy, its position and new rule inner the terrestrial ecosystem relationship, could change substantially. From a predatory and blindly destructive attitude, the human industrial system could learn new and instructive lessons from the Invisible Factories because the process of presumed autonomy and independence from. 


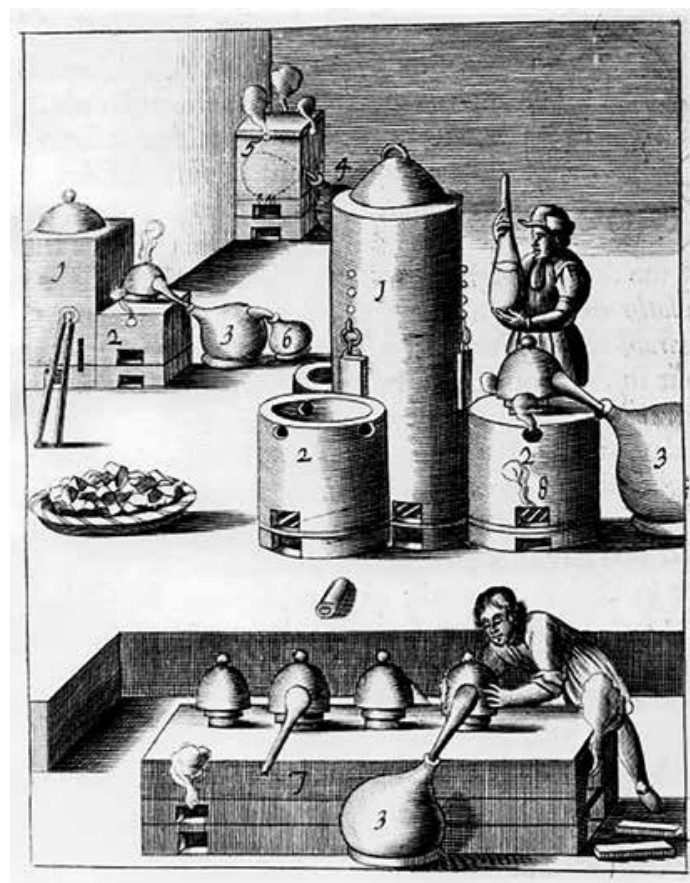

8

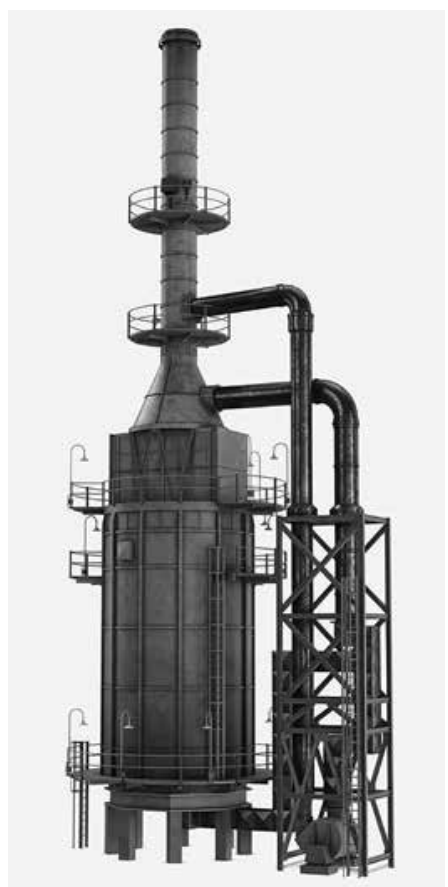

9

Figure 8. Cosmic Furnace-The Alchemic's Athanor (Credit https://www.researchgate.net/profile/ Christopher-Plaisance ). Figure 9. Crude fractional's oil distillation column (Credit Wiki).

Nature is still conducted today by the complex of economic and political actions of human communities with psychological schizoid traits. On the one hand, we are witnessing the reassuring persistence of a psychological and spiritual form of symbiosis with the Earth, which is recognized, as it probably happened at the dawn of humanity, as a considerable living super-organism (Hypothesis Gaia-Lovelock, 1979) and endowed with a sort of anima mundi. On the other side of the front, there are still old economic, financial, industrial, technological, and planning logics that derive from a mentality of the past that has forgotten that We cannot command Nature except by obeying her, as the great philosopher-scientist Francis Bacon had prophetically ruled centuries ago.

Technology and biocentrism seriously consider the idea of continuing with a certain humility to take lessons at school from Nature as they feel their artificial apprenticeship is somewhat incomplete and insecure, especially when verifying the examination of sustainability, functional and energy optimization, and global environmental impact ${ }^{17}$. 
Biomimetics and Bionics, which in the best manifestations represent a trend of careful biophilia, are an excellent example of this attitude of respect and desire for new alliances with Nature. This renewed ethical/aesthetic sentiment and this mindful awareness and respect for Nature is spreading in the cold and economics techno-scientific culture, moving in recent decades an impressive body of research and applications. The renewed attention to the systems of living beings redefines scientific and economic scenarios, ideologies, protocols as can be seen in Stefano Mancuso's pioneering research on plant intelligence and opposes the decadent, necrophilic, and destructive production, economic and technological logics inherited from the neoliberal industrial systems and consumerists who persist in maintaining the current status quo ${ }^{18}$.

The blind and relentless exploitation of terrestrial resources does not show any systemic and ecological consideration, which continues in the environmental destruction. Massive and devastating pollution will have to undergo a profound reconversion that can only start from renewal, increased with current progress, of the ancient feelings of biophilia, wonder, and awe that inhabited the eyes of the visitors of the past Wunderkammern. Exemplary is the third path developing in the promising artifice of the future of Neri Oxman's research work and design philosophy by his Mediated Matter Lab at MIT.

Oxman and his researchers have developed some of the most original and provocative concepts in the bio-design sector. They conceive in a sort of reverse biomimicry in which man, through that empathic process of biophilia, through the deep understanding and respect of Nature, does not intend to propose a mere mimicry for technological design. His proposal works to generate a bio-collaboration protocol in which living organisms cooperate to construct a hybrid product, as in the Silky Pavillon installation. According to Oxman's thought Nature, from Mother status, is transformed into a sort of Sister, which shows us her fragility, which requires us to listen to and respect its dynamic equilibrium as much as possible and with which to collaborate in a new vision of mediated artificiality ${ }^{19}$. Biomimetics, notwithstanding its extreme power, has not yet been able to achieve this competence, and in the future, will have to listen to lectio naturae for a long time to come.

\section{Notes}

1. Published in Italy in 1983 and subsequently translated into French, the book Naturalia et Mirabilia by Adalgisa Lugli, was one of the first studies that introduced the fascinating nature of Wunderkammern to a wider audience; the Italian edition of 2005 for the types of Mazzotta editore comes with an introduction by Roland Recht.

2. From the Greek $\theta \dot{\alpha} \alpha \tau \rho$ v, théatron, 'place of public spectacle', from the verb $\theta \varepsilon \dot{\alpha} o \mu \alpha$, theàomai, 'I observe', 'I look', the same root as theoreo, 'hence', 'theory'. It is interesting in the context of this essay to consider the common root that links the development of a theory to the act of observing and to "staging".

3. The italian philospher Bernardino Telesio (1509-1588) represents, in the history of Western philosophy, the moment of the transition from a vision of nature of a metaphysical type to one of an immanentistic type, even if not yet of a rationalistic and math- 
ematical type, as it will happen with Descartes and Galilei, nor of a purely materialistic and utilitarian, as was about to happen with Francis Bacon. In his De rerum natura iuxta propria principia, he proposes to explain nature and its phenomena, as the title declares, with his own principles, that is, without having recourse to any supernatural principle.

4. Henderson C., 2012, Il libro degli esseri a malapena immaginabili, Adelphi Edizioni, Milano, pg. 20.

5. Lumini M., 2019, Salire e scendere i passi della Scala Naturae al tempo degli Scanning Electron Microscope (SEM) della Biomimetica e delle nanotecnologie, in: Scienza Futura, Scienza Società Scienza , Cagliari, pgs. 58-73. https://issuu.com/ferrarif2/docs/scienza_fu tura_2019

6. Reference: https://www.anthropocene.info/

7. Lumini M., 2018, About Biomorphic Exuberance and Digital Rococo in Design an Parametric Contemporary Architecture, in: Pau F., Vargiu L., Following Forms, Following Functions. Pratices and Disciplines in Dialogue, Cambridge Scholars Publishing, pgs.123-143.

8. Biologist Janine Benjus have founded biomimicry3.8, the world's leading bio-inspired consultancy offering biological intelligence consulting, professional training, and inspiration, available for consultation at: https://biomimicry.net/

An other site of great interest for designers end researchers that works in biomimicry's step is: https://asknature.org

9. For a very interesting spiculae's design interpration see the Achim Menges's ICD Aggregate Pavilion 2018 - https://youtu.be/seOFklKRk0U

10. Nakayama S., Arima K, Kawai K., Fujimori T., Agata K, Funayama N., 2015, Dynamic Transport and Cementation of Skeletal Elements Build Up the Pole-and-Beam Structured Skeleton of Sponges, reference: https://core.ac.uk/download/pdf/82167886.pdf

11. Tsurkan D., Wysokowski M., Petrenko I., Voronkina A., Khrunyk Y., Fursov A., Ehrlich H., Modern scaffolding strategies based on naturally pre-fabricated 3D biomaterials of poriferan origin., reference: https://link.springer.com/article/10.1007/s00339-020-03564-9

12. Reference: https://jcs.biologists.org/content/116/7/1157

13. Mattheck C., Tesari I., 2000, Design in Nature., Institute for Materials Research II Forschungszentrum Karlsruhe, Germany Reference:https://www.witpress.com/Secure/ elibrary/papers/ENV00/ENV00020FU.pdf

14. This definition refers to an aphorism attributed to the Greek philosopher Plato in his dispute with Diogenes, reference: https://www.laphamsquarterly.org/animals/miscellany/ plato-and-diogenes-debate-featherless-bipeds

15. References: https://www.britannica.com/technology/nanotechnology/Bottom-up-approach

16. Reference: http://www.dierk-raabe.com/hierarchical-architecture-of-chitin/

17. Lumini M., 2018, Biomimetics: Nature's teaching., MIUR-BIONIKONLab - Iglesias

Reference: https://issuu.com/massimolumini/docs/issuu

https://advances.sciencemag.org/content/3/10/eaao2047

18. Reference: https://www.newyorker.com/magazine/2013/12/23/the-intelligent-plant

19. Reference video: https://youtu.be/CVa_IZVzUoc 


\section{References}

Arber A. (1985). The Mind and the Eye. A study of the biologist's standpoint, Cambridge Unversity Press, Cambridge, NY.

Arruda, A. J.V. (2018). Métodos e processos em biônica e biomimética: a revolução tecnológica pela naturaleza, Blucher Open Access, São Paolo.

Benjus J. (1998). Biomimicry. Innovation Inspired by Nature, Harper Collins, NY.

Giacomoni, P. (1993). Le Forme e il Vivente. Morfologia e filosofia della natura in J.W. Goethe, Guida Editori, Napoli.

Harman, J. (2014). The Shark's Paintbrush. Biomimicry and how Nature is inspiring innovation, White Cloud Press, Ashland, OR.

Henderson, C. (2018). Il libro degli esseri a malapena immaginabili, Adelphi Edizioni, MI

Lugli A., 2005, Naturalia et Mirabilia. Il collezionismo enciclopedico nelle Wunderkammern d'Europa, Mazzotta, MI.

Mauriès, P. (2002). Le Stanze delle Meraviglie, Rizzoli, MI.

Salvia, G.; Rognoli, V. \& Levi, M. (2009). Il Progetto della Natura. Gli strumenti della biomimesi per il design, Franco Angeli, MI.

Resumen: Wunderkammern mostró su Mirabilia, las cosas naturales (naturalia) o hechas por humanos (artificialia) más raras. El Antropoceno crea un gabinete digital de TechWonders que dificulta distinguirlos. Las nanotecnologías manipulan la materia a un nivel microscópico nunca alcanzado por la tecnología humana y generan criaturas moleculares con propiedades extraordinarias. Pero a pesar de esto, todavía no pueden competir con el sollertiam de la naturaleza que actúa dentro de las Fábricas Invisibles, donde las comunidades celulares cobran vida a partir de materia inorgánica. A pesar de su poder de diseño extremo, la biomimética aún no ha alcanzado esta competencia. Tendrá que escuchar lectio naturae durante mucho tiempo en el futuro.

Palabras clave: Wunderkammern - Mirabilia - Naturalia - Artificialia - Fábricas invisibles - Biomiméticos - Antropoceno - Nanotecnologías - Jerarquías biológicas - Sostenibilidad

Abstract: Wunderkammern mostrou a ela Mirabilia, as coisas naturais mais raras (naturalia) ou feitas pelo homem (artificialia). O Antropoceno faz um Gabinete Digital de TechWonders que torna difícil distingui-los. As nanotecnologias manipulam a matéria em um nível microscópico nunca alcançado pela tecnologia humana e geram criaturas moleculares com propriedades extraordinárias. Mas, apesar disso, eles ainda não podem competir com o sollertiam da Natureza atuando dentro das Fábricas Invisíveis, onde comunidades celulares ganham vida a partir de matéria inorgânica. Apesar de seu extremo poder de design, a biomimética ainda não alcançou essa competência. Terá que ouvir a lectio naturae por muito tempo no futuro. 
Palavras chave: Wunderkammern - Mirabilia - Naturalia - Artificialia - Fábricas invisíveis Biomimética - Antropoceno - Nanotecnologias - Hierarquias biológicas - Sustentabilidade 